\title{
PHASE TRANSITION IN NIOBIUM PENTOXIDE SUPPORTED ON SILICA-ALUMINA
}

\author{
V. S. Braga ${ }^{1}$, F. A. C. Garcia ${ }^{2}$, J. A. Dias ${ }^{2 *}$ and Sílvia C. L. Dias ${ }^{2}$ \\ ${ }^{1}$ Universidade Federal da Bahia (UFBA), Instituto de Ciências Ambientais e Desenvolvimento Sustentável (ICADS) \\ Rua Professor José Seabra S/N, Barreiras-BA, 47805-100, Brazil \\ ${ }^{2}$ Universidade de Brasília, Instituto de Química, Laboratório de Catálise, caixa postal 04478, Brasília-DF, 70904-970, Brazil
}

\begin{abstract}
$\mathrm{Nb}_{2} \mathrm{O}_{5}$ supported on $\mathrm{SiO}_{2}-\mathrm{Al}_{2} \mathrm{O}_{3}$ were prepared with a wide loading range $(2,5,10,15,20$ and 25 mass $\%)$ and analyzed by simultaneous thermogravimetric (TG) and differential thermal analysis (DTA). The materials presented a phase transition close to $1364^{\circ} \mathrm{C}$. This phase transition was studied by XRD, FTIR and Raman spectroscopy. A mixture of orthorhombic (T) and monoclinic (H and M) crystalline phases was evidenced in the supported samples, which is coverage dependent, in contrast to the formation of only the monoclinic phase ( $\mathrm{H}$ and $\mathrm{M})$ when pure $\mathrm{Nb}_{2} \mathrm{O}_{5}$ is heated under the same conditions. These results indicate the stabilization of $\mathrm{Nb}_{2} \mathrm{O}_{5}$ on silica-alumina surface.
\end{abstract}

Keywords: niobium pentoxide, phase transition, silica-alumina, supported catalyst, thermal analysis

\section{Introduction}

Niobium pentoxide supported on high surface area oxides is used as an acid-redox catalyst for a variety of chemical reactions (e.g., esterification, hydration, etc.) [1-3]. Depending on the surface coverage, mono-oxo isolated, polymerized or bulk species may be formed [4]. These surface species are responsible for the new properties and enhanced catalytic activity of these materials [5].

Thermal stabilities of the supported oxides change dramatically in comparison with the bulk oxide. For instance, a mixed oxide containing 25 mass $\%$ of $\mathrm{Nb}_{2} \mathrm{O}_{5}$ and 75 mass $\%$ of $\mathrm{SiO}_{2}$ heated at $1000^{\circ} \mathrm{C}$ forms a hexagonal (TT) phase of $\mathrm{Nb}_{2} \mathrm{O}_{5}$, while pure $\mathrm{Nb}_{2} \mathrm{O}_{5}$ forms the same phase at $450-500^{\circ} \mathrm{C}$ [6]. The phase transition of $\mathrm{Nb}_{2} \mathrm{O}_{5}$ can be used as a criterion to establish the degree of interaction between the two oxides [6].

The polymorphism in $\mathrm{Nb}_{2} \mathrm{O}_{5}$ is temperature dependent and crystallization is influenced by the starting material, impurities, and interaction with other components. The main crystalline forms of $\mathrm{Nb}_{2} \mathrm{O}_{5}$ are hexagonal (TT), orthorhombic (T or $\gamma$ ), monoclinic (M or $\beta$ ), and monoclinic (H or $\alpha)$ [7]. There is some controversy whether TT and M phases are really crystalline forms. Nevertheless, the existence of these polymorphs is important for the reactivity of any niobium containing material [6].

The structure of niobium oxide supported on silica-alumina has recently been characterized [8]. A phase transition for the material pre-calcined at $800^{\circ} \mathrm{C}$ was observed about $1356^{\circ} \mathrm{C}$ by simultaneous
TG/DTA analysis. Even though the process occurred at high temperature, the crystalline form of supported niobium pentoxide was not fully characterized. Therefore, the goal of this work was to characterize in detail the crystalline phase formed using thermal analysis, X-ray diffraction (XRD), infrared (FTIR) and Raman spectroscopy.

\section{Experimental}

Preparation of $\mathrm{Nb}_{2} \mathrm{O}_{5}$ supported on $\mathrm{SiO}_{2}-\mathrm{Al}_{2} \mathrm{O}_{3}$

An aqueous solution of ammonium niobium oxalate, $\mathrm{NH}_{4}\left[\mathrm{NbO}\left(\mathrm{C}_{2} \mathrm{O}_{4}\right)_{2}\left(\mathrm{H}_{2} \mathrm{O}\right)_{2}\right]\left(\mathrm{H}_{2} \mathrm{O}\right)_{\mathrm{n}}$, obtained from Companhia Brasileira de Metalurgia e Mineração (CBMM), was added to a glass round bottom flask containing silica-alumina (Aldrich) at 1:10 mass ratio of solid to water. Silica-alumina was activated by calcination at $550^{\circ} \mathrm{C}$ for $12 \mathrm{~h}$ in order to transform it from ammonium to protonated form. The amount of niobium precursor was calculated to obtain 2, 5, 10, 15, 20 and 25 mass \% loadings of $\mathrm{Nb}_{2} \mathrm{O}_{5}$. The system was stirred at $80^{\circ} \mathrm{C}$ until the water had completely evaporated. The solid was removed, ground to finer particles and placed in an oven at $150^{\circ} \mathrm{C}$ for $2 \mathrm{~h}$ before further analysis.

\section{Thermoanalytical, XRD and spectroscopic analyses}

Thermal analysis data were obtained in a simultaneous TG-DTA model SDT 2960 from TA Instruments, at a scan rate of $10^{\circ} \mathrm{C} \mathrm{min}{ }^{-1}$ in the $25-1400^{\circ} \mathrm{C}$ range under nitrogen $(99.999 \%)$ flow of $110 \mathrm{~mL} \mathrm{~min}{ }^{-1}$. Platinum

* Author for correspondence: jdias@unb.br 
pans with about $20 \mathrm{mg}$ of sample were used in all runs with $\alpha-\mathrm{Al}_{2} \mathrm{O}_{3}$ as reference. At least three replicate experiments were recorded and the samples collected to obtain enough material for the spectroscopic analyses.

$\mathrm{X}$-ray powder diffraction patterns were recorded on a Rigaku D/Max-2A/C spectrometer with $\mathrm{CuK \alpha}$ radiation of $1.5418 \AA$ ( $40 \mathrm{kV}$ and $20 \mathrm{~mA})$. A $2 \theta$ range from 2 to $60^{\circ}$ was scanned at $1.8^{\circ} \mathrm{min}^{-1}$. Crystalline phases were identified by comparison with PDF database from ICDD included in the software JADE 3.0.

Infrared spectra were recorded on a Bruker Equinox 55 spectrometer with 128 scans and spectral resolution of $4 \mathrm{~cm}^{-1}$ in dried 1 mass $\% \mathrm{KBr}$ (Merck) pellets. FT-Raman spectra of samples were obtained at room temperature $\left(25^{\circ} \mathrm{C}\right)$ with 128 scans at a resolution of $2 \mathrm{~cm}^{-1}$ on a Bruker FRA 106/S module attached to the Equinox 55 spectrometer. The wavelength and laser (Nd-YAG) power were $1064 \mathrm{~nm}$ and $126 \mathrm{~mW}$, respectively. A liquid nitrogen cooled Ge detector collected the Raman signal. Infrared and Raman spectra were obtained under ambient conditions and baseline corrected.

\section{Results and discussion}

\section{Preliminary analysis}

The theoretical monolayer of supported $\mathrm{Nb}_{2} \mathrm{O}_{5}$ on silica-alumina $\left(475 \mathrm{~m}^{2} \mathrm{~g}^{-1}\right)$ is close to $39.6 \mathrm{mass} \%$ loading, which may be calculated based on the dimension of the $\mathrm{Nb}_{2} \mathrm{O}_{5}$ crystal unit reported in the literature $\left(0.32 \mathrm{~nm}^{2}\right)$ [9]. Nonetheless, the experimental data based on XRD and Raman measurements established that the actual monolayer is obtained with $\mathrm{Nb}_{2} \mathrm{O}_{5}$ loading between 10 and 15 mass\% [8]. Thus, the materials with 2 and 5 mass $\%$ are below the monolayer while those with 15-25 mass\% are above monolayer.

In order to look at the effects of loading and decomposition of the precursor on the support, previous studies revealed that pure crystalline oxalate has an amorphous pattern at heating temperatures of $300-400^{\circ} \mathrm{C}$ for $6 \mathrm{~h}$. This pattern is also observed for $\mathrm{Nb}_{2} \mathrm{O}_{5} / \mathrm{SiO}_{2}-\mathrm{Al}_{2} \mathrm{O}_{3}$ heated at $300^{\circ} \mathrm{C} / 6 \mathrm{~h}$. Thus, the decomposition of oxalate groups is expected to occur close to $300^{\circ} \mathrm{C}$ and it is highly dependent on the degree of interaction with the support during thermal treatment. Further details regarding this decomposition will be provided in the following sections.

\section{Simultaneous TG/DTA}

The DTG curves of $\mathrm{Nb}_{2} \mathrm{O}_{5} / \mathrm{SiO}_{2}-\mathrm{Al}_{2} \mathrm{O}_{3}$ are presented in Fig. 1 and display a profile that depends on the initial loading of the niobium precursor. For the samples with low contents $(2-10 \%)$ there are two mass loss peaks centered close to 60 and $300^{\circ} \mathrm{C}$ associated with the

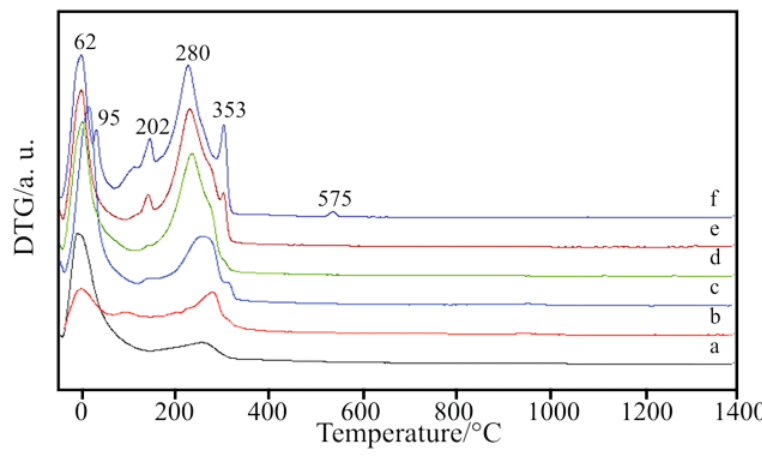

Fig. 1 DTG curves of the samples with: $a-2, b-5, c-10$, $\mathrm{d}-15, \mathrm{e}-20$ and $\mathrm{f}-25$ mass $\%$ loadings of $\mathrm{Nb}_{2} \mathrm{O}_{5} / \mathrm{SiO}_{2}-\mathrm{Al}_{2} \mathrm{O}_{3}$, respectively

desorption of physically and chemically adsorbed water and the decomposition of oxalate, respectively. On the other hand, the samples with $15-25 \%$ showed a displacement of the maximum temperature to higher values and fine characteristics in the range of $200-400^{\circ} \mathrm{C}$ (peaks at 202,280 and $353^{\circ} \mathrm{C}$ ). All these events are related to complete decomposition of the supported ammonium niobium oxalate precursor, as comprised by FTIR analysis of the samples calcined up to $400^{\circ} \mathrm{C}$ [8].

In order to be sure on these assignments and to compare the DTG/DTA profile obtained with the behavior of the niobium precursor a DTG/DTA curve is provided for pure ammonium niobium oxalate (Fig. 2). The DTG curve shows basically six mass loss peaks, which correspond to five events in DTA curve: $i$ ) four endothermic peaks at 167,240 and $268^{\circ} \mathrm{C}$, which are related to the release of physisorbed and chemisorbed water, and ammonium desorption, respectively; $i$ ) two exothermic peaks at 268 and $541^{\circ} \mathrm{C}$, attributed to partial and total decomposition of oxalate, respectively. The mass loss at offset $\left(\sim 610^{\circ} \mathrm{C}\right)$ of the highest temperature peak is consistent with the complete conversion of the ammonium oxalate to niobium pentoxide, as calculated by the theoretical value. Those assignments are in agreement with other works related to oxalate precursor decompositions $[10,11]$.

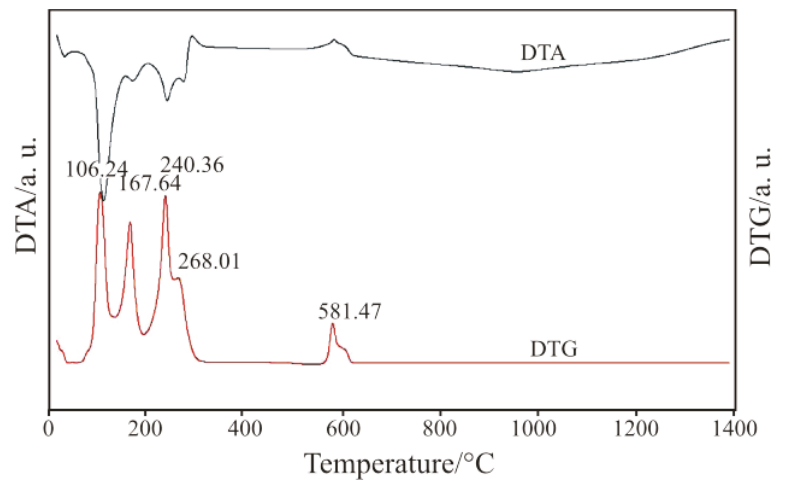

Fig. 2 DTG/DTA curves of ammonium niobium oxalate $\left(\mathrm{NH}_{4}\left[\mathrm{NbO}\left(\mathrm{C}_{2} \mathrm{O}_{4}\right)_{2}\left(\mathrm{H}_{2} \mathrm{O}\right)_{2}\right]\left(\mathrm{H}_{2} \mathrm{O}\right)_{\mathrm{n}}\right)$ 


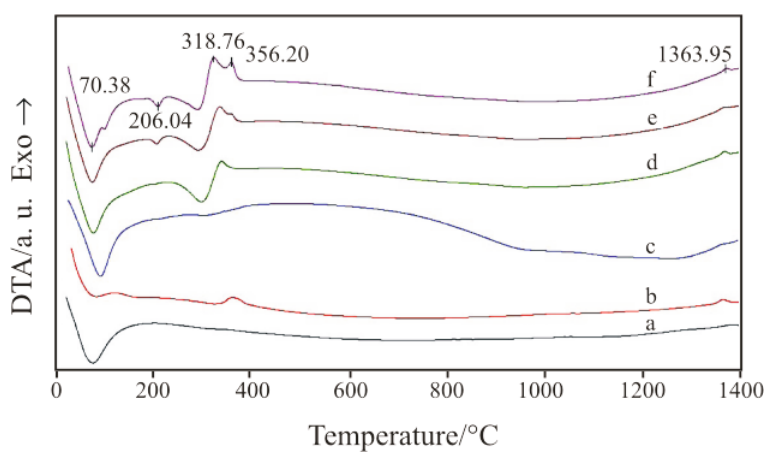

Fig. 3 DTA curves of the samples with: a $-2, b-5, c-10$, $\mathrm{d}-15, \mathrm{e}-20$ and $\mathrm{f}-25$ mass $\%$ loadings of $\mathrm{Nb}_{2} \mathrm{O}_{5} / \mathrm{SiO}_{2}-\mathrm{Al}_{2} \mathrm{O}_{3}$, respectively

The DTA curves (Fig. 3) display, for the samples with $15-25 \%$ a large endothermic peak centered about $70^{\circ} \mathrm{C}$ (in the range of $30-150^{\circ} \mathrm{C}$ ) relative to water desorption processes. In addition, there are two endothermic peaks at about 206 and $300^{\circ} \mathrm{C}$, which are assigned to ammonia desorption and $\mathrm{CO}$ and/or $\mathrm{CO}_{2}$ from the catalyst surface during the decomposition of the niobium complex, respectively. Moreover, there are three additional exothermic peaks. The ones at 319 and $356^{\circ} \mathrm{C}$ are attributed to oxalate decomposition and the third one around $1364^{\circ} \mathrm{C}$ is related to a phase transition (no mass loss in the DTG curve). The profile of DTA curves for the samples with $2-10 \%$ is different in temperatures higher than $150^{\circ} \mathrm{C}$. No marked peaks for the precursor decomposition were observed, probably because of the large background signal of DTA and the low initial oxalate content. Moreover, no transition phase for the sample with $2 \%$ was observed.

A phase transition peak was observed (at about $1356^{\circ} \mathrm{C}$ ) for the $\mathrm{Nb}_{2} \mathrm{O}_{5} / \mathrm{SiO}_{2}-\mathrm{Al}_{2} \mathrm{O}_{3}$ samples pre-calcined at $800^{\circ} \mathrm{C}$ [8] with a larger area, indicating that previous calcination facilitates the formation of $\mathrm{Nb}_{2} \mathrm{O}_{5}$ crystallites. This phase transition is attributed to $\mathrm{Nb}_{2} \mathrm{O}_{5}$ since pure $\mathrm{SiO}_{2}-\mathrm{Al}_{2} \mathrm{O}_{3}$ did not show any thermal event under the same temperature range studied. Characterization of the crystalline phase formed in the TG/DTA experimental conditions was performed by XRD, FTIR and Raman techniques.

\section{X-ray powder diffraction}

In order to confirm that the exothermic peaks displayed in the DTA curves represent phase transitions, XRD of the samples was taken before and after TG/DTA experiments. The samples of $\mathrm{Nb}_{2} \mathrm{O}_{5} / \mathrm{SiO}_{2}-\mathrm{Al}_{2} \mathrm{O}_{3}$ after impregnation but without calcination did not show any XRD pattern of the crystalline ammonium niobium oxalate or niobium pentoxide crystalline phase (Fig. 4). These results confirmed that the impregnation process generates either a very disperse and amorphous supported niobium complex or particles that are too small to be de-

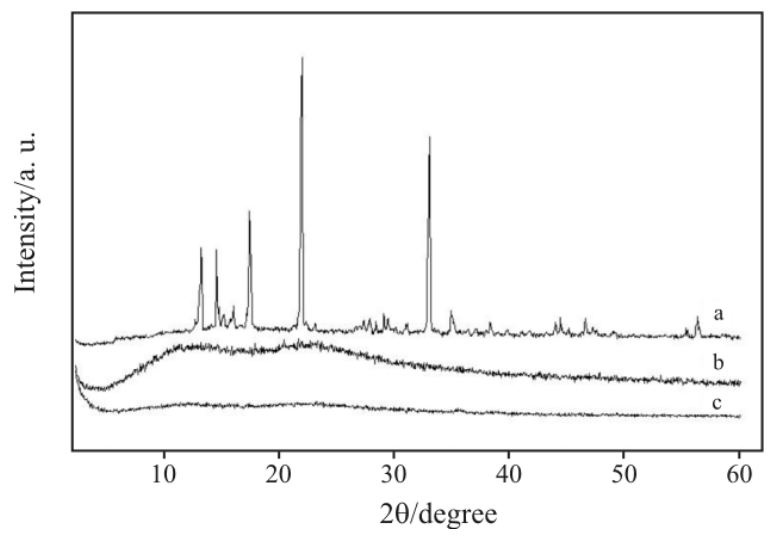

Fig. 4 XRD of: $\mathrm{a}-\mathrm{NH}_{4}\left[\mathrm{NbO}\left(\mathrm{C}_{2} \mathrm{O}_{4}\right)_{2}\left(\mathrm{H}_{2} \mathrm{O}\right)_{2}\right]\left(\mathrm{H}_{2} \mathrm{O}\right)_{\mathrm{n}}$, $\mathrm{b}-25 \% \mathrm{Nb}_{2} \mathrm{O}_{5} / \mathrm{SiO}_{2}-\mathrm{Al}_{2} \mathrm{O}_{3}$ without calcination, c - silica-alumina after TG/DTA experiment

tected by powder XRD. Pure $\mathrm{Nb}_{2} \mathrm{O}_{5}$ showed a crystalline pattern equivalent to monoclinic form $(\mathrm{H}$ and $\mathrm{M})$ after TG/DTA experiment (Fig. 5). Silica-alumina did not show any phase transition when heated under the same temperature range and established an amorphous pattern with or without [8] calcination (Fig. 4).

The supported samples with $15-25 \%$ of $\mathrm{Nb}_{2} \mathrm{O}_{5}$ displayed reflections that had contributions from the predominantly monoclinic $(\mathrm{H}$ and $\mathrm{M})$ together with orthorhombic $(\mathrm{T})$ crystalline structures (Figs $5 \mathrm{e}-\mathrm{g}$ ). The support imposes less mobility to $\mathrm{Nb}_{2} \mathrm{O}_{5}$ because of its interaction with silica-alumina. Thus, the reactivity of supported niobium pentoxide, regarding phase transitions, decreases when compared to the pure oxide, since it forms a crystalline phase that is usually obtained at a lower temperature. This reactivity is coverage dependent [8] and formation of high temperature phases is attributed to a weaker interaction with the support [6]. This is demonstrated by the behavior of the supported samples with $2-10 \%$ of

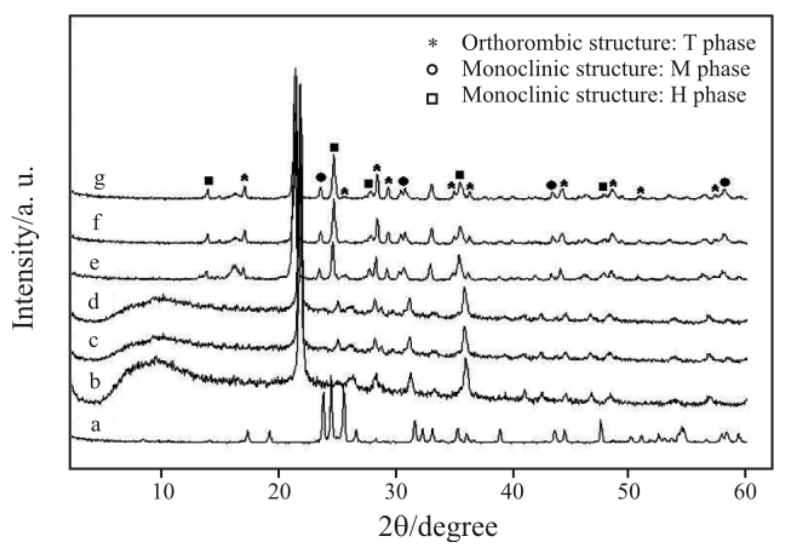

Fig. 5 XRD pattern of the samples: $\mathrm{a}-$ pure $\mathrm{Nb}_{2} \mathrm{O}_{5}$ and supported with: $\mathrm{b}-2, \mathrm{c}-5, \mathrm{~d}-10, \mathrm{e}-15, \mathrm{f}-20$ and $\mathrm{g}-25$ mass $\%$ loadings of $\mathrm{Nb}_{2} \mathrm{O}_{5} / \mathrm{SiO}_{2}-\mathrm{Al}_{2} \mathrm{O}_{3}$, after TG/DTA experiments. Note that the most intense peak of supported samples shifts from $2 \theta=22.6$ (T-phase, b-d) to $2 \theta=22.3$ (H-phase, e-g) 
$\mathrm{Nb}_{2} \mathrm{O}_{5}$, which are composed of predominantly orthorhombic $(\mathrm{T})$ phase and presence of monoclinic $(\mathrm{H}$ and $\mathrm{M}$ ) crystalline structures (Figs $5 \mathrm{~b}-\mathrm{d}$ ). It should be noted that the most intense reflection peak shifts from $2 \theta=22.6$ (T-phase) to $2 \theta=22.3$ (H-phase) with the increase in $\mathrm{Nb}_{2} \mathrm{O}_{5}$ loading.

\section{FTIR and Raman spectroscopy}

The changes in the spectra of supported $\mathrm{Nb}_{2} \mathrm{O}_{5}$ on silica-alumina obtained after calcination at $800^{\circ} \mathrm{C}$ are subtler [8], but the same samples display new absorptions after the TG/DTA experiments. Silica-alumina has strong peaks at $\sim 1096 \mathrm{~cm}^{-1}\left(\mathrm{v}_{\mathrm{as}(\mathrm{Si}-\mathrm{O})}\right)$, with a shoulder at $\sim 1200, \sim 930 \mathrm{~cm}^{-1}$ (external $v_{\mathrm{Si}_{-} \mathrm{O}^{-}}$), $\sim 805 \mathrm{~cm}^{-1}\left(v_{\mathrm{s}\left(\mathrm{Si}_{-} \mathrm{O}_{-}^{-}\right)}\right)$, and weak peaks at $\sim 720 \mathrm{~cm}^{-1}$ $\left(v_{\mathrm{Al}-\mathrm{O}}\right), \sim 576 \mathrm{~cm}^{\mathrm{s}\left(\mathrm{Si}^{-1}\right)}$ (external $\left.\delta_{{\mathrm{Si}-\mathrm{O}^{-}}^{-}}\right)$, and $\sim 467 \mathrm{~cm}^{-1}$ $\left(\delta_{\mathrm{Si}-\mathrm{O}-\mathrm{Si}}\right)[12]$. The supported samples $(15-25 \%)$ after thermal analysis experiments showed additional absorptions (Fig. 6). These absorptions at $\sim 950$ and $850 \mathrm{~cm}^{-1}\left(v_{\mathrm{Nb}=\mathrm{O}}\right.$ of highly distorted $\left.\mathrm{NbO}_{6}\right), \sim 714 \mathrm{~cm}^{-1}$ $\left(\mathrm{Nb}-\mathrm{O}-\mathrm{Nb}\right.$ chain linkages) and $\sim 620 \mathrm{~cm}^{-1}$ ( $v_{\mathrm{Nb}-\mathrm{O}}$ of slight distorted $\mathrm{NbO}_{6}$ ) [13] are assigned to the presence of bulk niobium pentoxide species. For the lower supported samples $(2-10 \%)$ not all absorptions are present. The main bands are assigned at 990, 790, 620 and $490 \mathrm{~cm}^{-1}$ (except $10 \%$, which has an additional band at $\left.850 \mathrm{~cm}^{-1}\right)$. These samples are loaded below monolayer, and thus the bands are related to the presence of either isolated or polymerized $\mathrm{Nb}_{2} \mathrm{O}_{\mathrm{x}}$ species on the silica-alumina surface [8].

Further evidence of niobium oxide interaction on silica-alumina surface is obtained by the Raman spectra (Fig. 7). Silica-alumina has weak Raman bands in the range of 400-1000 $\mathrm{cm}^{-1}$ [8]. Supported samples with higher coverage (15-25\%) displayed bands at $933 \mathrm{~cm}^{-1}$ (with shoulders at 955 and $995 \mathrm{~cm}^{-1}$ ), and smaller bands at 795, 729, $605 \mathrm{~cm}^{-1}$. These absorptions are attributed to terminal $\mathrm{Nb}=\mathrm{O}$ bonds on highly distorted $\mathrm{NbO}_{6}$ species, $\mathrm{Nb}-\mathrm{O}$ bonds in slighted dis-

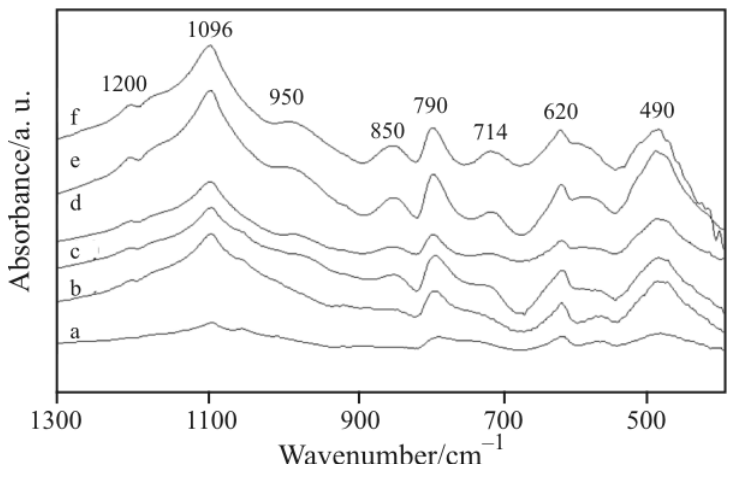

Fig. 6 FTIR spectra of the samples with: $a-2, b-5, c-10$, $\mathrm{d}-15, \mathrm{e}-20$ and $\mathrm{f}-25$ mass $\%$ loadings of $\mathrm{Nb}_{2} \mathrm{O}_{5} / \mathrm{SiO}_{2}-\mathrm{Al}_{2} \mathrm{O}_{3}$, after TG/DTA experiments

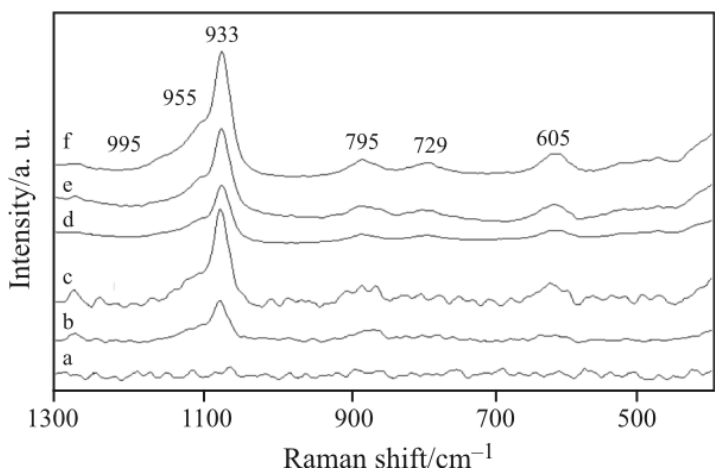

Fig. 7 Raman spectra of the samples with: $a-2, b-5, c-10$, $\mathrm{d}-15, \mathrm{e}-20$ and $\mathrm{f}-25$ mass\% loadings of

$\mathrm{Nb}_{2} \mathrm{O}_{5} / \mathrm{SiO}_{2}-\mathrm{Al}_{2} \mathrm{O}_{3}$, after TG/DTA experiments

torted $\mathrm{NbO}_{6}, \mathrm{NbO}_{7}$ and $\mathrm{NbO}_{8}$ polyhedra species and $\mathrm{Nb}-\mathrm{O}-\mathrm{Nb}$ angle deformations, respectively [14-16] present on bulk $\mathrm{Nb}_{2} \mathrm{O}_{5}$. It is interesting to note that the Raman spectrum of $\mathrm{Nb}_{2} \mathrm{O}_{5}$ agrees with the formation of $\mathrm{H}$ phase (presence of a band at $995 \mathrm{~cm}^{-1}$ ) [17, 18]. Thus, coupling Raman spectroscopy with XRD analysis enabled the conclusion that H-phase is the predominant form of niobium pentoxide after thermal analysis experiments. The samples with lower coverage $(2-10 \%)$ have bands consistent with the presence of both isolated and polymerized species on the surface (main bands at 940 and $630 \mathrm{~cm}^{-1}$ ), except the $2 \%$ sample that presents very broad bands consistent with the ones observed in materials with highly dispersed $\mathrm{Nb}_{2} \mathrm{O}_{\mathrm{x}}$ species [8].

\section{Conclusions}

Simultaneous TG-DTA analyses of $\mathrm{Nb}_{2} \mathrm{O}_{5} / \mathrm{SiO}_{2}-\mathrm{Al}_{2} \mathrm{O}_{3}$ materials showed a phase transition at about $1364^{\circ} \mathrm{C}$. This phase transition was studied by XRD, FTIR and Raman spectroscopy. Based on these results, a mixture of orthorhombic (T) and monoclinic (H and $\mathrm{M})$ structures was evidenced in the supported samples, in contrast to the formation of only monoclinic phase $(\mathrm{H})$ when pure $\mathrm{Nb}_{2} \mathrm{O}_{5}$ is heated under the same conditions. The degree of the mixture depends on the $\mathrm{Nb}_{2} \mathrm{O}_{5}$ loading, since T-phase predominates in samples with low coverage (2-10 mass \%) while H-phase dominates in those with high coverage (15-25 mass \%).

\section{Acknowledgements}

We thank Prof. Edi Mendes Guimarães from Laboratório de Difração de Raios-X (IG/UnB) for XRD measurements, CBMM for donation of the niobium compounds, $\mathrm{CNPq}$ for scholarship to pursue Doctorate degree (V.S.B) and financial support given by UnB-IQ (FUNPE), FINATEC, CNPq, FAPDF/SDCT/CNPq and FINEP/CTPetro. 


\section{PHASE TRANSITION IN NIOBIUM PENTOXIDE}

\section{References}

1 K. Tanabe, Catal. Today, 78 (2003) 65.

2 M. Ziolek, Catal. Today, 78 (2003) 47.

3 I. Nowak and M. Ziolek, Chem. Rev., 99 (1999) 3603.

4 J. M. Jehng and I. E. Wachs, Catal. Today, 8 (1990) 37.

5 I. E. Wachs, Catal. Today, 27 (1996) 437.

6 E. I. Ko and J. G. Weissman, Catal. Today, 8 (1990) 27.

7 H. Schäfer, R. Gruehn and F. Schulte, Angew. Chem. Int. Ed. Engl., 5 (1966) 40.

8 V. S. Braga, J. A. Dias, S. C. L. Dias and J. L. de Macedo, Chem. Mater., 17 (2005) 690.

9 T. Onfroy, G. Clet, S. B. Bukallah, D. M. Hercules and M. Houalla, Catal. Lett., 89 (2003) 15.

10 A. Ubaldini, C. Artini, G. A. Costa, M. M. Carnasciali and R. Masini, J. Therm. Anal. Cal., 84 (2006) 207.

11 A. O. S. Silva, V. J. Fernandes Jr. and A. S. Araujo, J. Therm. Anal. Cal., 64 (2001) 1147.
12 A. Corma and J. Pérez-Pariente, Appl. Catal., 63 (1990) 145.

13 J. M. Jehng and I. E. Wachs, Chem. Mater., 3 (1991) 100.

14 J. M. Jehng and I. E. Wachs, J. Mol. Catal., 67 (1991) 369.

15 I. E. Wachs, J. M. Jehng, G. Deo, H. Hu and N. Arora, Catal. Today, 28 (1996) 199.

16 J. M. Jehng and I. E. Wachs, Catal. Today, 16 (1993) 417.

17 T. Ikeya and M. Senna, J. Non-Cryst. Solids, 105 (1988) 243.

18 B. X. Huang, K. Wang, J. S. Church and Y.-S. Li, Electrochim. Acta, 44 (1999) 2571.

Received: December 29, 2006

Accepted: May 10, 2007

DOI: $10.1007 / \mathrm{s} 10973-006-8325-4$ 